\title{
Luther Burbank (1849-1926)
}

\author{
Mary E. Dale \\ Professional Service Industries, Inc., 22711 La Palma Ave., Yorba Linda, CA 92687
}

Luther Burbank, horticulturist, plant wizard, Sage of Santa Rosa (California), was born in Lancaster, Mass., on 7 Mar. 1849. His love of plants was cultivated on the family farm, but his thirst for science started while attending the Lancaster Academy. A Professor Gunning lectured on many scientific subjects at the Academy and made a lasting impression on the young Burbank. About this same time, at the age of 19, Burbank read a book from the public library, about which he said in a 1909 letter, . . . "was the turning point of my career in fixing my life work in the production of new species and varieties of plant life..." (Kellogg, 1958). The book was Charles Darwin's Variation of Animals and Plants Under Domestication. When Darwin noted that plants adopted crossfertilization for the plant's advantage and benefit, Burbank thought, why not use this same system for the advantage and benefit of man? This was Burbank's starting point (Howard, 1945a).

The goal of his breeding work was "the production of more and better varieties of cultivated plants" (Kellogg, 1958). He accomplished this goal many times over through huge hybridization experiments and by using his eye for selecting desirable characteristics. In his work he "brought to light the absurdity of reasoning from inadequate data..." (Howard, 1945a).

He was the "Henry Ford" of hybridization, and this was one of his secrets (Dreyer, 1985). He mass-produced thousands of seedlings to arrive at a single improved variety. Onto his hundreds of stock trees he grafted dozens of hybrid plums. He used many of the techniques familiar to European horticulturists that were not yet known to Americans, and Burbank had to "rediscover" them on his own. After meeting Burbank, the famous Dutch botanist Hugo de Vries noted that Burbank had a "special gift of judgment, in which he excels all his contemporaries" (Dreyer, 1985).

His ability to recognize characteristics, his production-line hybridization, and other bold ventures-such as accepting a Mar. 1881 order to produce 20,000 prune trees for fall planting, and succeeding by using a new technique (in California), June buddingadded to his mystique and reputation as the

Received for publication 4 June 1991. Appreciation is expressed to Kay Voliva, Coordinator, Luther Burbank Home and Gardens. Santa Rosa, Calif. The information, contact, and photographs she provided were invaluable.

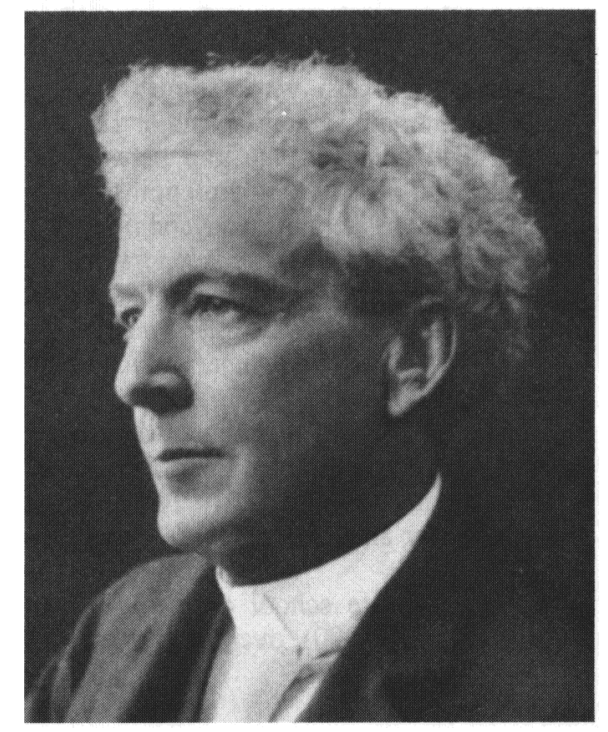

extensive list and description of Burbank's plant contributions. In it there are 27 fruits, from apple to wonderberry; four nuts (including his walnut); nine grains, grasses, or forage crops, from barley to wheat; $26 \mathrm{veg}$ etables, from artichoke to tomato; and 91 ornamental plants, from abutilon to zinnia (including his still-popular Shasta daisy and the fragrant calla). Within each of these crops there are one or more varieties listed, such as 113 under plum and prune. When he started his work on plums, there were only two types available.

During his lifetime, Burbank introduced more than 800 new varieties of plants (in all horticultural commodities) and worked with nearly 200 genera (Kellogg, 1958). According to Howard (1945b), Burbank "probably contributed or introduced more plants than any other single American in our history."

His first success was the ancestor of today's Idaho Russet potato-the Burbank potato. In 1873, while still in Massachusetts, he discovered a seed ball on a potato plant and from it selected a seedling that developed into the large white, durable, finegrained, and now famous potato. He used the money from the sale of the rights to his potato to pay for the train ticket that was to bring him to Santa Rosa, Calif. When he arrived in 1875, he found a land ripe for his work, and of it he said "I firmly believe, from what I have seen, that this is the chosen spot of all this earth as far as Nature is concerned" (Luther Burbank Home \& Gardens, 1990).

\section{OTHER CONTRIBUTIONS} ard, 1945a).

\section{BURBANK'S "NEW CREATIONS"}

Burbank called his introductions "new creations" and published a catalog of them each year from 1893 to 1901 . He had an extraordinarily keen perception for recognizing (by sight, touch, and smell) what to most was imperceptible among a mass of seedlings. According to Kellogg (1958), this was his genius.

His work with plums spanned 40 years and resulted in more than 40 new varieties. This work was the beginning of California's major fruit production industry, and helped make Sonoma County the eighth largest agricultural county in the country by 1920 . He spent 16 years developing new lilies and used more than 50 varieties for hybridization. During this time he developed the fragrant calla lily.

W.L. Howard (1945b) produced the most
If Burbank had given us only the Burbank potato, the Shasta daisy, and his many plums, he still would have made his mark and contributed greatly to horticulture. He did much more.

His controversial work stimulated the development of plant breeding and advanced it 20 years by arousing the interest of researchers and institutions toward plant breeding. Many believe that this is his most important contribution (Dreyer, 1985; Howard, 1945a). Burbank's paper "Another Mode of Species Forming," presented to the American Breeders Assn. meeting in 1909, reported the phenomenon of the true-breeding species hybrid. No one believed him, and it would be 20 years before science would recognize this hybrid. Burbank, however, was not given credit for reporting it first (Dreyer, 1985). He was interested in producing more and better plants, and may be regarded as one of 
the fathers of agribusiness (Dreyer, 1985), and he can be credited with popularizing horticulture and making it a household word (Luther Burbank Home \& Gardens, 1990). He lived in the time of Henry Ford and Thomas Edison-both of whom were his friends-all self-made men of the industrial age.

In 1905, fame led to his receipt of a 10year \$10,000-per-year grant and an assistant, George Shull, from the Carnegie Inst. The idea was to collect scientific data during Burbank's work. But, he did not keep clear scientific records, and, after 5 years, by mutual agreement, the grant was terminated (Kellogg, 1958).

Throughout his life, Burbank sought support for plant patent laws, but was not successful. Therefore, many of his plants were marketed by other nurseries, and his work brought him limited financial rewards. He was, however, granted plant patent \#15 posthumously for 'July Elberta' peach, which was acquired by Stark Brothers Nursery after his death. This patent is the basis for his 1986 induction into the National Inventors Hall of Fame (Blackman et al., 1989). Ironically, it was Burbank who indirectly, but significantly, contributed to the passing of the first plant patent law.

In 1930, the average congressman knew very little about horticulture, and the adoption of the proposed plant patent law seemed doubtful. The major stumbling block was Rep. Fiorello La Guardia. When the sponsor of the bill, Fred Purnell, asked La Guardia what he thought of Luther Burbank, La Guardia enthusiastically said he thought Burbank was one of "the greatest Americans that ever lived." Purnell then continued to read, for the record, a letter written to Paul Stark by Burbank before he died. Burbank wrote of his despair over the lack of protection for a plant breeder's investment of time and energy. He continued, that while someone's mousetrap could be patented, and their "nasty song" copyrighted, "...if he gives to the world a new fruit that will add millions to the value of earth's annual harvest he will be fortunate if he is rewarded by so much as having his name connected with the result." Burbank went on to add that only the surface has been scratched and there was an immeasurable amount of experimentation to be done, yet he could not recommend the brightest, most promising man to make plant breeding his work until America took action to protect his rights. La Guardia then took the floor, withdrew his objection, and moved to adopt the bill. It passed the House and the Senate with no further problems (Dreyer, 1985).

\section{EPILOGUE}

On 11 Apr. 1926, at the age of 77, Burbank died. At his request, he was buried in an unmarked grave in front of his cottage under the Cedar of Lebanon tree he had planted there in 1893.

Burbank made significant and positive contributions to horticulture. He has been honored by California when, in 1909, it passed a bill declaring 7 Mar. (the date of his birth) as State Bird and Arbor Day. In 1985, he was inducted into the Agriculture Hall of Fame (K. Voliva, personal communication).

These honors are fitting. It was Howard (1945a) who wrote objectively about Burbank's work and recommended that "For these concrete accomplishments and because he was the ferment that stirred others to advance the science of breeding, an intangible achievement, to be sure, but his greatest from the viewpoint of science, he is definitely entitled to a place in the hall of fame..." Fortysix years later his words still apply.

\section{Literature Cited}

Blackman, D, B. Hornback, T.A. Brown, and R. Bicknell. 1989. Fifty famous favorites. Luther Burbank Home \& Gardens.

Dreyer, P. 1985. A gardener touched with genius, the life of Luther Burbank. rev. ed. Univ. of California Press, Berkeley.

Howard, W.L. 1945a. Luther Burbank-A victim of hero worship. Chronica Bot. 9(5-6):299-506.

Howard, W.L. 1945b. Luther Burbank's plant contributions. California Agr. Expt. Sta. Bul. 691.

Kellogg, V. 1958. Luther Burbank, p. 265-270. In: A. Johnson and D. Malone (eds.). Dictionary of American biography. vol II. BrearlyCushing. Scribner's, New York.

Luther Burbank Home \& Gardens. 1990. Luther Burbank Gardener to the world. 


\title{
William H. Chandler (1878-1970)
}

\author{
Adel A. Kader and Cathey Wolpert \\ Department of Pomology University of California, Davis, CA 95616
}

William H. Chandler was born on 31 July 1878 in Butler, Mo. He attended the Univ. of Missouri, Columbia, where he received his BS, MS, and $\mathrm{PhD}$ in agriculture in 1905 , 1906, and 1914, respectively.

Chandler's career led him from the Univ. of Missouri, Columbia, to the Univ. of California, Berkeley and Davis first, then to Los Angeles and Riverside. His initial appointment at the Univ. of Missouri in 1905 was a fellow in horticulture. In 1906, he accepted the position of assistant in horticulture, which was followed by his appointment of instructor in 1908; by 1910, he was promoted to assistant professor. Chandler moved to Ithaca, N.Y., in 1913, accepting the position of professor of pomology at Cornell Univ. While at Cornell (1920-23), he served the campus administration as vice-director of research.

The Univ. of California was successful in attracting Chandler to the Berkeley campus. In 1923 he accepted the chairmanship in the Dept. of Pomology, for both the Berkeley and Davis campuses. Chandler left Berkeley in 1937 and relocated to the Los Angeles campus. He held the position of assistant dean at UCLA in charge of the Agricultural activities at Los Angeles and Riverside before retiring in 1948 .

Chandler received numerous honors, including his election as President of ASHS in 1921 and vice president of the American Association for the Advancement of Science in 1939. He was elected to membership in the National Academy of Sciences in 1943 and as faculty research lecturer on the UCLA campus in 1944. In 1951, he was recognized by he American Society of Plant Physiologists when the organization awarded him the Charles Reid Barnes Honorary Life Membership. He was elected Fellow of ASHS in 1965.

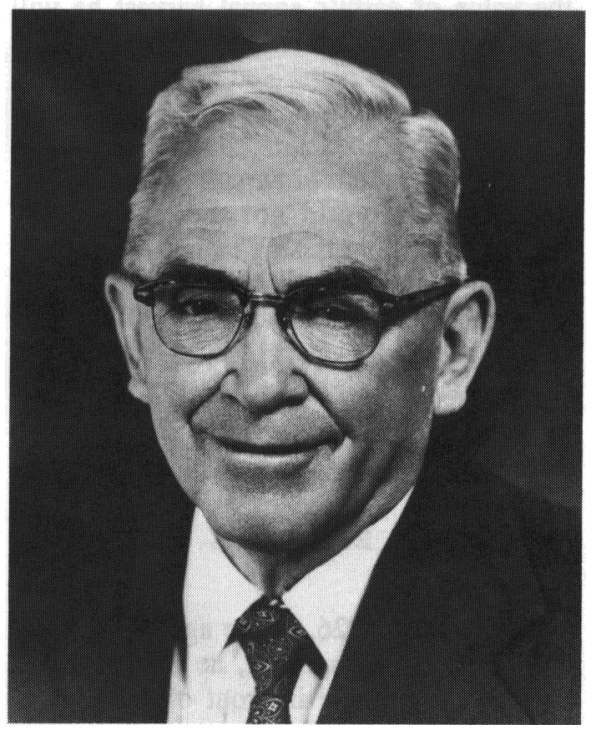

Chandler made outstanding contributions to horticulture and teaching, including the horticultural books Fruit Growing (published in 1925) and North American Orchards: Their Crops and Some of Their Problems (published in 1928). The former, which was 10 years in preparation, is still regarded as a classic in its field. Some of his books were translated into various foreign languages, including Hebrew and Russian. Of major importance are Chandler's later books, entitled Deciduous Orchards and Evegreen Orchards, published in 1942 and 1950, respectively. These books have been used as texts and reference books, and are still used today as very useful and important sources of information.

Chandler was renowned for his discovery that the little-leaf or rosette disease of fruit trees and mottle leaf in citrus was due to a zinc deficiency. This was a discovery of fun- damental importance that led to the development of a routine treatment that is of major economic importance today, and could be said to have been the forerunner of foliar application of nutrients in the broad sense.

Chandler was an important pioneer in controlled studies of woody plant cold hardiness. His publication "The Killing of Plant Tissue by Low Temperature," released in 1913, is considered a classic, as is his review "Cold Resistance in Horticultural Plants," published in the Proceedings of the American Society for Horticultural Science in 1954. The latter set standards for understanding the low temperature problem. It has been said that if one's findings were not consistent with the Chandler view, it was wise to think it through one more time.

Another important contribution, resulting from his studies on bud dormancy, was the effect that environmental factors, particularly chilling, had on dormancy. Chandler was involved in breeding apples with low chilling requirements, resulting in the 'Beverly Hills' apple, successfully grown in southern California and similar climatic regions, and the introduction of 'Caroline', a wisteria that performs well in regions with mild winters. He also investigated pruning fruit trees and ornamentals, plant saps, and polarity and scion rooting.

Chandler's interests were broad, embracing not only all aspects of horticulture, but also everyday affairs of the world. He was an extraordinary horticulturist with strong devotion and personal commitment to research and graduate education. Chandler is remembered for his kindness and sensitivity and the quiet, pervasive, positive influence he had on those around him. By the time of his death on 29 Oct. 1970, Prof. William H. Chandler was recognized as the Dean and Senior Statesman of American Horticulturists. 


\title{
Henry A. Jones (1889-1981)
}

\author{
P.W. Simon ${ }^{1}$ \\ U.S. Department of Agriculture, Agricultural Research Service, Vegetable Crops Research Unit, Department of \\ Horticulture, University of Wisconsin, Madison, WI 53706
}

W.H. Gabelman'2
Department of Horticulture, University of Wisconsin, Madison, WI 53706

D.F. Franklin ${ }^{3}$

Department of Horticulture, University of Idaho Research and Extension Center, Parma, ID 83660

\begin{abstract}
Henry A. Jones was one of the great pioneers in agriculture. He is most widely remembered for his original research on the genetics of cytoplasmic-genic male sterility in onions and consequent development of methods to apply this discovery for the production of $F_{1}$ hybrid seed, which has been useful in a wide range of horticultural and agronomic crops. His revelation, study, and application of cytoplasmic-genic male sterility tied together the creative insight of scientific discovery to the successful application of a basic biological phenomenon in a way rarely accomplished in agriculture. In 1925 he first discovered (in a single bulb of the 'Italian Red' onion cultivar) what he proved to be cytoplasmic-genic male sterility; by 1944 he developed 'California Hybrid Red No. 1' (Fig. 1), the first hybrid in any crop based on the use of cytoplasmic-genic male sterility; today, a significant proportion of the onions in the world are hybrids using cytoplasmic-genic male sterility. Moreover, similar systems of male sterility have since been used in producing hybrids of other crops, including carrots, beets, petunias, maize, sorghum, rice, wheat, and many others. Without the pioneering research of Jones, the advantages of cytoplasmic male sterility would have likely gone unrecognized for some time. Because of their vigor and uniformity, hybrid crop cultivars are familiar to not only scientists, but to- the general public as well. Yet, hybrids are only feasible for a limited number of crops without the method of cytoplasmic-genic male sterility discovered and put into use in onion by Jones. T.W. Whitaker (1983) aptly stated that, "Dr. Jones' discovery of a self-sterile onion bulb in 1925 was the origin of a major revolution in agriculture and the seed industry."
\end{abstract}

Jones was born in 1889 in Deer Park, Ill., and grew up helping his family with market

\footnotetext{
Received for publication 3 June 1991. Research supported by USDA/ARS, and College of Agriculture and Life Sciences, Univ. of WisconsinMadison.

${ }^{1}$ Research Geneticist and Professor.

${ }^{2}$ Professor.

${ }^{3}$ Research Professor Emeritus.
}

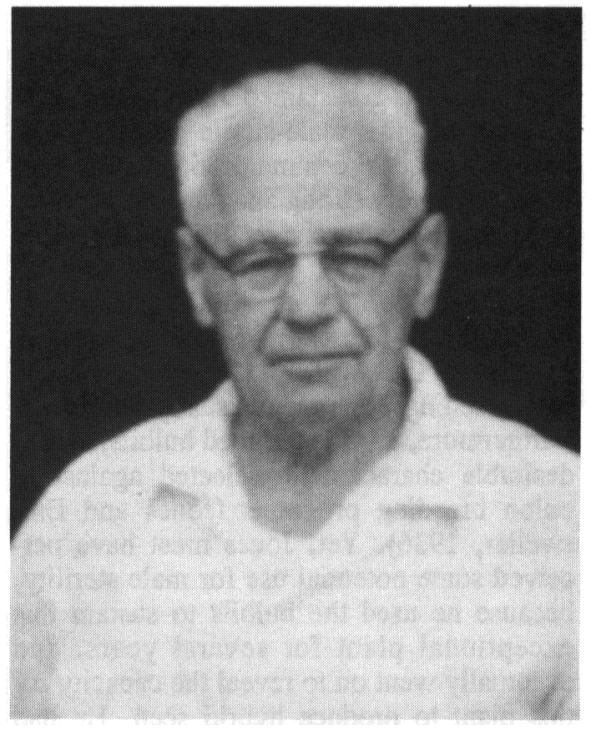

followed by 2 years as professor of vegetable gardening at the Univ. of Maryland. While in West Virginia, he began research for his first publication (Jones, 1920). This work was completed in Maryland and dealt with a problem familiar to him since his youthonion dormancy. During his last summer at Maryland, Jones recruited Victor Boswell as a graduate student. Although the duration of their relationship was brief, Boswell received an indelible impression of Jones as a remarkably versatile botanist and botanical illustrator; a man of few, but very well-chosen, words; and a well-trained, competitive boxer. Jones had high expectations of those who worked with him, yet years later he did not expect his subordinates and colleagues to perform certain routine tasks. For example, he insisted on filling seed packets of his onion breeding lines for distribution to his cooperators, since he felt they were a significant reflection of himself (V. Boswell, personal communication). With Boswell, Jones initiated his first research on onion reproductive biology at Maryland (Jones and Boswell, 1922).

In 1922, Jones accepted an invitation to direct the Division of Truck Crops at the Univ. of California, Davis, as associate professor. He developed a broad program studying the morphology, reproductive biology, and disease resistance of vegetable crops with J.T. Rosa. Resulting from this cooperation was the classic text "Truck Crop Plants" (Jones and Rosa, 1928). Some of the original studies of onion, asparagus, lettuce, carrot, peas, brassica, cauliflower, beet, and snapdragon(!) also came from this program, as did a small group of graduate students, many of whom went on to make outstanding contributions to horticulture on their own. These students include S.L. Emsweller, G.C. Hanna, Helen (nee Monosmith) Pearson, O.H. Pearson, and T.W. Whitaker.

It was during his years from 1922 to 1936 at UC-Davis that Jones made his key discoveries and initial observations on cytoplasmic-genic male sterility. Although the developments from this important work with onion are probably most often remembered by students today, it is interesting to note that, through 1932, 15 of his 20 bulletins and 


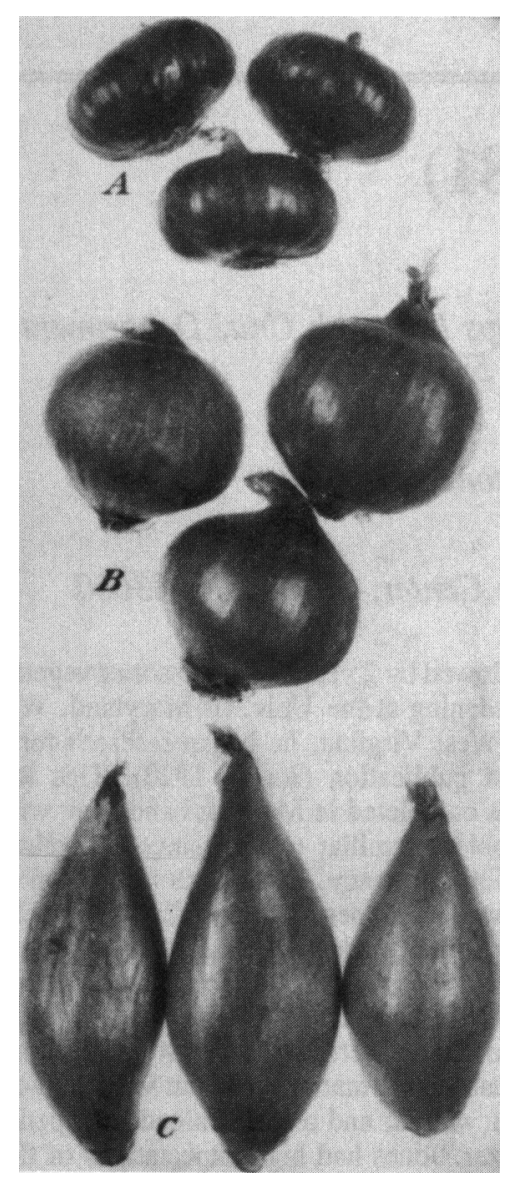

Fig. 1. California Hybrid Red No. 1 Onion (B), the fit hybrid in any crop developed using cytoplasmic-genic male sterility, and its two-component inbred parents, Lord Howe Island (A), and male-sterile Italian Red (C).

refereed papers dealt with crops other than onion-lettuce (e.g., Jones, 1927, Jones and Tavernetti, 1932) and, especially, asparagus (e.g., Jones, 1932; Jones and Robbins, 1924, 1926, 1928; Robbins and Jones, 1925, 1926). The first three papers of his career dealt with onions and reported work completed before or soon after he arrived in California. Two of these three papers dealt with onion reproductive biology. His next two onion papers dealt with seed (Jones, 1927) and bulb (Jones, 1929) production. Even though asparagus production stands out as at least equal to his onion breeding efforts in publications through 1932, Jones stated that his own efforts had been "devoted chiefly to onion breeding" in his 1932 American Society for Horticultural Science Presidential Address (Jones, 1932). This fact was emphatically documented by 10 more onion breeding papers before he left UC-Davis, and only three more papers on other crops. Thus, there was no question that onion breeding was his major emphasis. Included in these onion breeding papers were three important publications documenting the Allium fistulosum $\times$ A. cepa interspecific hybrid, one of which was published in Science (Emsweller and Jones, 1935a-c).

Another interesting point surfaces in the account of onion breeding presented by Jones in his ASHS Presidential Address. He contrasted his selection for vigor and uniformity with mass selection in onion with the ability to create vigorous and uniform $F_{1}$ hybrids in corn by emasculation (detasselling). He stated somewhat ruefully that, in onion, "obviously the same technique cannot be used as with corn, because it is impracticable to emasculate large numbers of flowers" (Jones, 1932). This statement suggests that, although he found the ultimate source of onion male sterility in 1925 , work by Jones and his students by 1932 did not suggest a definitive system to create $F_{1}$ hybrids in onion on demand. Low seed set kept population sizes too small to determine the mode of inheritance. It was not until about 1936 that enough $\mathrm{F}_{1}$ hybrid onion seed was produced to start trial evaluations and begin assessing inheritance patterns. Thus, scientific curiosity is thought to have sustained Jones' interest in maintaining the male-sterile onion (O.H. Pearson, personal communication). This was, however, a very strong and unusual curiosity for a man who was, by all accounts, very practical.

The male-sterile 'Italian Red' onion plant, designated 13-53, was undesirable in several ways (Fig. 2). A plant failing to bear seed in a breeding program is usually discarded. Furthermore, 13-53 produced bulbils, an undesirable characteristic selected against in onion breeding programs (Jones and Emsweller, 1936). Yet, Jones must have perceived some potential use for male sterility, because he used the bulbils to sustain this exceptional plant for several years, and eventually went on to reveal the capacity for this plant to produce hybrid seed. He had observed the uniformity, but loss of vigor, on inbreeding as well as striking heterosis in hybrid onions produced by hand emascula-

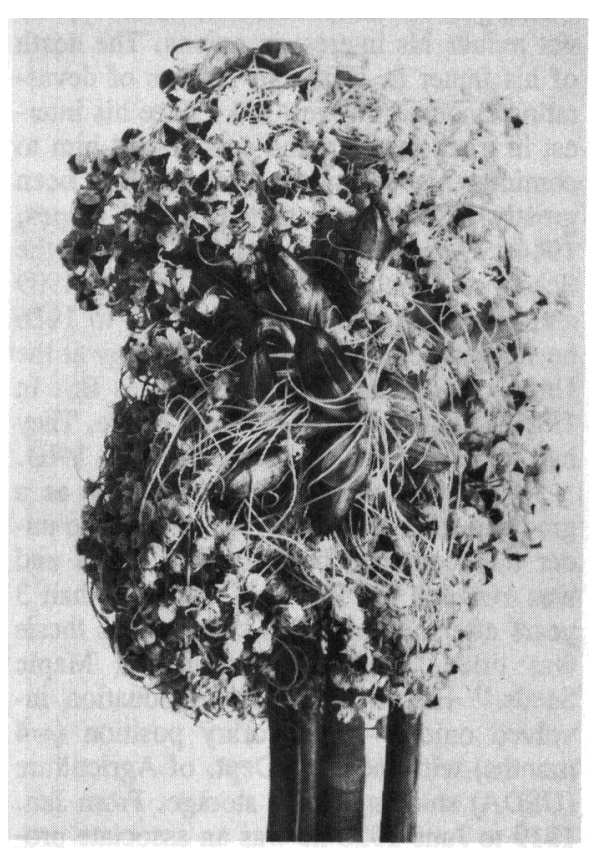

Fig. 2. An umbel of onion Italian Red 13-53 with both bulbils and seed. tion (Jones and Emsweller, 1933; Jones, 1937), and he had developed systems for rearing and using insect pollinators (Jones and Emsweller, 1934). He had evaluated methods for improving seed set, and studied onion productive biology. History does not reveal the level of planning and extent of searching that went into the discovery of 'Italian Red 13-53'; thus, the details of events surrounding this exceptional discovery and the creative insight to apply male sterility go unrecorded. The consequences of this event, fortunately, are well-documented and we continue to reap their benefits.

In 1936, Jones left California to take charge of the USDA onion and potato investigations in Beltsville, Md. It is here that he took the basic information he generated on onion male sterility to develop the hybrid seed production techniques we use today. He continued to publish, primarily on onion breeding, to yield 32 more onion papers and bulletins and five more on other crops before his last publication, the classic "Onions and their Allies" in 1963, with L.K. Mann. His important contributions to spinach breeding are included in these works (Jones et al., 1956). Yet, the 1943 paper describing the inheritance of onion genic-cytoplasmic male sterility, 18 years after its discovery, stands as the classic of Jones' career (Jones and Clarke, 1943). As discussed by Gabelman (Janick, 1989), this paper documents the genetic basis of the system used to economically and reliably produce $F_{1}$ hybrid seed, first in onion and later in a wide range of crops. Without a reliable genetic basis to condition male sterility predictably, hybrid cultivars would only be used in a few crops. Furthermore, the subtleties of this system are unlikely to have been used without the foresight, diligence, and hard work of Jones to prove that this system worked biologically and could be handled by a seed trade familiar only with open-pollinated cultivars. Fortunately, the use of this system was not stifled by a patent. Jones saw the national scope of a USDA program as necessary to make hybrid onions successful. Other male-sterile onions have been sought and found, but the 'Italian Red 13-53' accounts for most, if not all, of the onion genic-cytoplasmic male sterility currently in use. Work continuing today interestingly indicates that the male-sterile cytoplasm in onion may well be that of a species other than Allium cepa (X. Havey, personal communication).

In addition to his research talents, Jones was an excellent organizer and leader. He initiated an exemplary, broad-based cooperative program to develop, test, and release onions across the United States, and he oversaw the development of a similar program in potatoes. As a leader of the National Onion Breeding Program, he established a unique network of collaborators, which served two primary purposes. First, cooperators across the country were able to remain current on the best production and storage practices and latest cultivars available because Jones traveled to the up to 22 testing sites across the country each year evaluating onion produc- 
tion and storage trials. Interaction with his cooperators was also a vital part of the success of this program. Although his classroom teaching skills were not highly regarded, his interaction with individuals and small groups was superb. Some of these cooperators were, or are, the leading onion breeders-testing the best germplasm available at the time and developing even better material in their programs (Figs. 3 and 4). These included E.W. Davis and G. McCollum (Idaho), W.C. Edmundson (Colorado), D.F. Franklin (Idaho), W.H. Gabelman (Wisconsin), A.E. Kehr (Iowa), and H. Munger (New York). Second, Henry Jones was able to use the network of cooperators to see that the hybrid onion technique was in fact working as planned; that seed producers were able to use his new, more-complicated method of seed production effectively with acceptable seed yields, and hybrids were as uniform in fullscale production as they were in small test plots. Thus, Jones was able to successfully transfer the technology for commercial seed production to the seed industry and the technology and strategies for developing onion hybrids to both public and private onion breeders. He developed more than 50 onion hybrids for use across North America, several of which are still in production today. The onion hybrids developed by Jones were used not only in North American production areas, but also in several major foreign onion-growing districts. In addition to the increased yield, uniformity, and more-stable productivity imparted by the hybrid onions he developed, improved resistance to diseases and pests, including downy mildew (Jones et al., 1939), smut (Walker et al., 1944), smudge (Jones et al., 1946), thrips (Jones et al., 1934), and particularly pink root (Porter and Jones, 1933; Perry and Jones, 1955; Jones and Perry, 1956), was incorporated into inbreds and hybrids he developed. With these accomplishments and 39 years of public service, Jones was not yet ready to retire at age 68 . In 1957 , he left the USDA/ARS and became director of research for the Desert Seed Co., El Centro, Calif. He deliberated at great length to reach this decision, but, in the end, chose to move to a position where he could see the application of his discovery on the largest possible scale. He spent 22 productive years in industry, and thus covered the full picture of science and technology first-hand from discovery to description to field testing to full-scale commercial production.

We can enthusiastically agree with Jones, who said "I am indeed glad that those numb fingers and cold feet in boyhood did not forever keep me away from onions" (Jones, 1944). He was fortunate to be able to see the complete development of a curiosity with some vague possibilities to a very widely used technique of commerce (Fig. 5). He served as President of ASHS in 1932, and received numerous awards recognizing his accomplishments, including the Vaughan Award in 1943 from ASHS for his paper with A.E. Clarke (Jones and Clarke, 1943), the Herbert Medal in 1944 from the Amer-

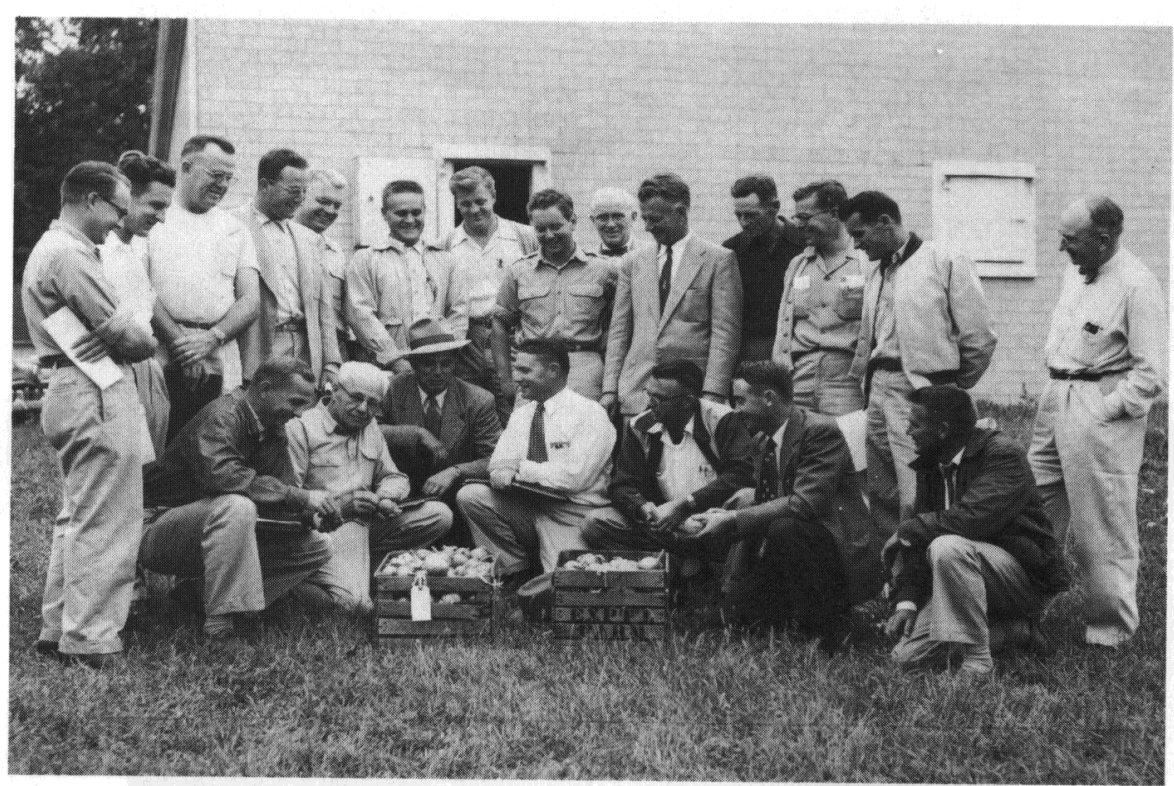

Fig. 3. Henry Jones and cooperators at Hybrid Onion Field Day, Michigan State College Muck Farm, 16 Sept. 1954. Front row (left to right): W. Gabelman, Univ. of Wisconsin; H. Jones, U.S. Dept of Agriculture; E. Owen, Ferry-Morse Seed Co.; C. Peterson, Michigan State College; D. Franklin, Univ. of Idaho; R. Lucas, Michigan State College; and W. Scott, Joseph Harris Seed Co. Standing (left to right): P. Bessey, Michigan State College; S. Wittwer, Michigan State College; P. Olesen, Crookham Seed Co.; S. Ries, Michigan State College; A. Kehr, Iowa State College; J. Weigle, Michigan State College; H. Tiessen, Michigan State College; L. Rappaport, Michigan State College; R. Marshall, Michigan State College; R. Carolus, Michigan State College; K. Trapp, Trapp Bros., Beulah, Mich.; J. Lingle, Michigan State College; B. McDonald, Crookham Seed Co.; and F. Davis, Michigan State College.

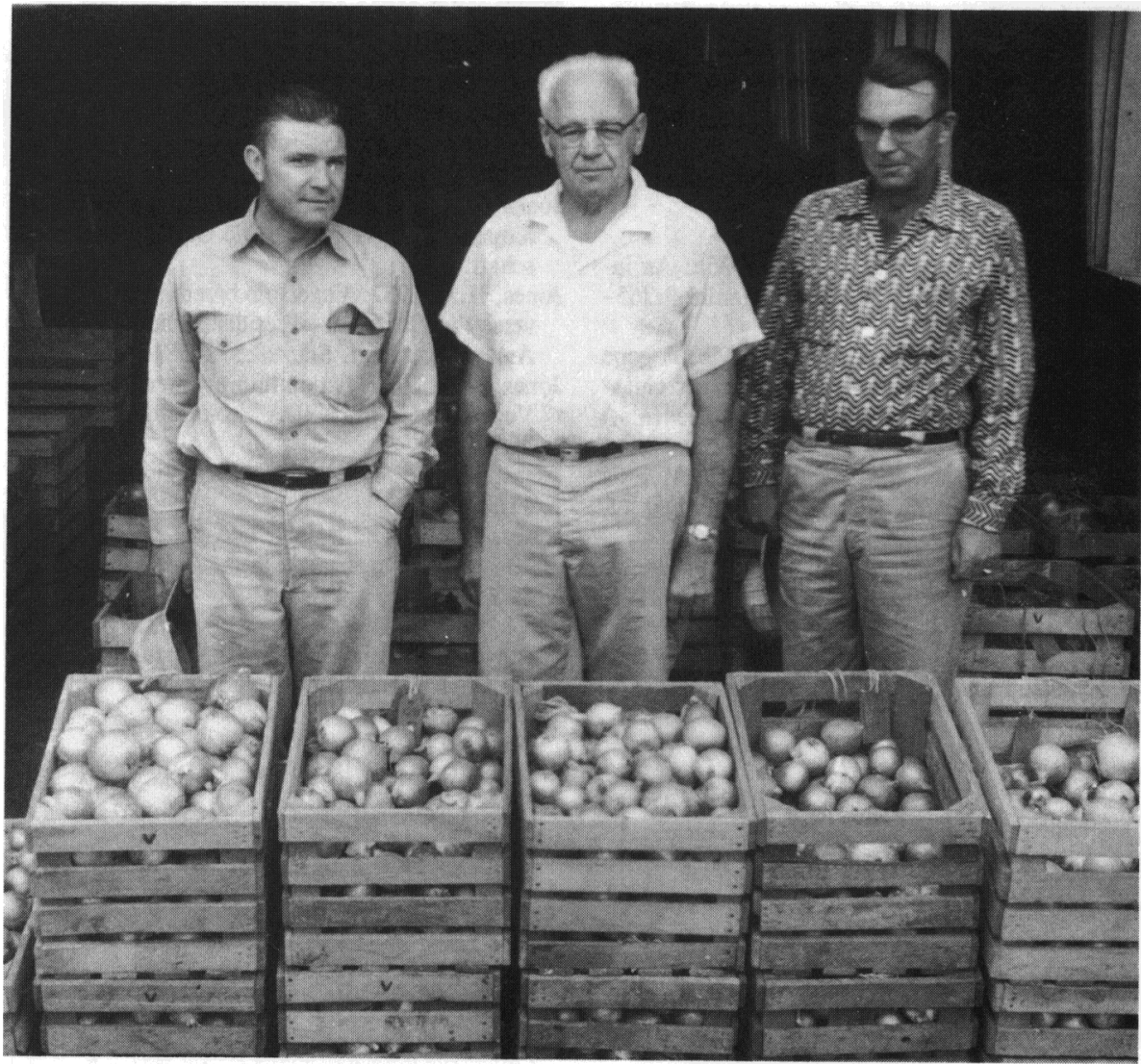

Fig. 4. Henry Jones (center) and cooperators C.E. Peterson (left) and D.F. Franklin (right). 


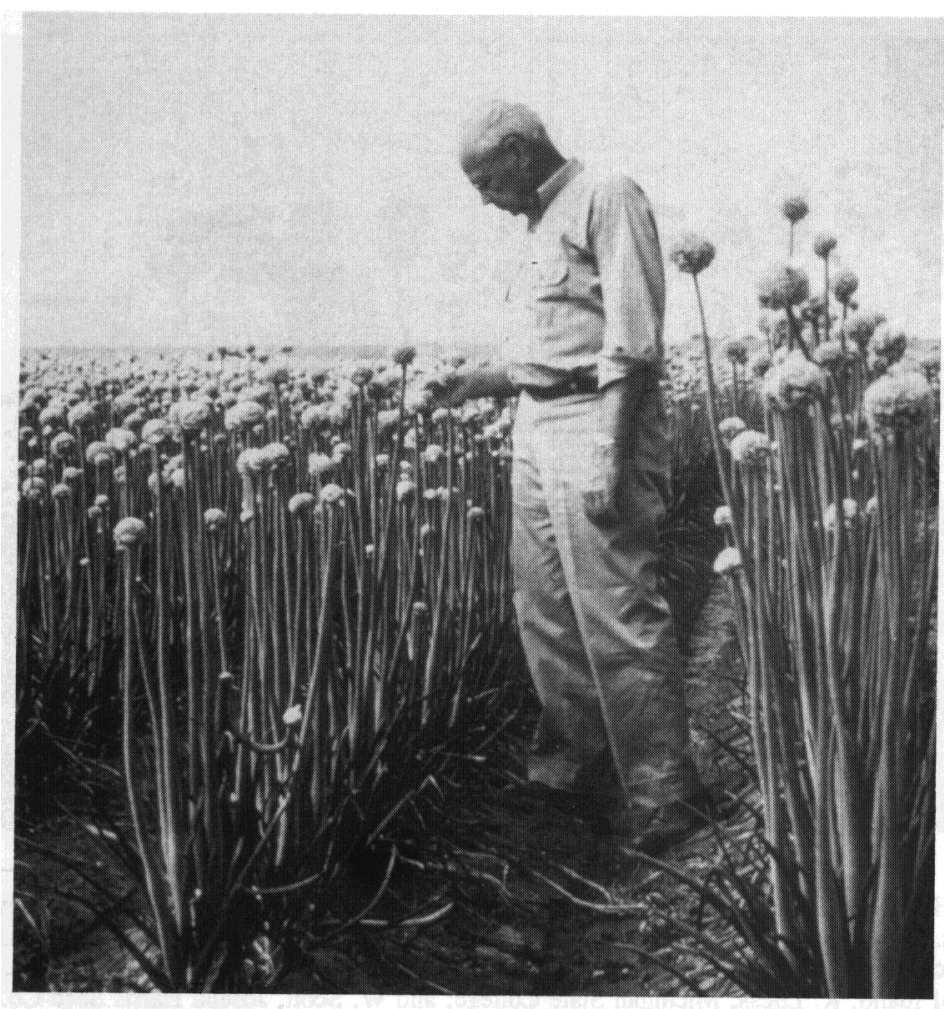

Fig. 5. Jones evaluating onion flowers.

ican Plant Life Society, an honorary DS in 1952 from the Univ. of Nebraska, and the USDA Distinguished Service Award in 1953.

Henry A. Jones was a wise, considerate, humble man with great vision and tenacity. He embodied the characteristics of seeking, finding, and applying knowledge of horticulture, and science in general, for our greater good. He is a most fitting member for the Horticulture Hall of Fame.

\section{Literature Cited}

Emsweller, S.L. and H.A. Jones. 1935a. An interspecific hybrid in Allium. Hilgardia 9:265213.

Emsweller, S.L. and H.A. Jones. 1935b. A gene for control of interstitial localization of chiasmata in Allium fistulosum L. Science (n.s.) 81:543-544.

Emsweller, S.L. and H.A. Jones. 1935c. Meiosis in Allium fistulosum, Allium cepa, and their hybrid. Hilgardia 9:277-294.

Janick, J. (ed.). 1989. Classic papers in horticultural science. Prentice Hall, Englewood Cliffs, N.J.

Jones, H.A. 1920. Preliminary report on onion dormancy studies. Proc. Amer. Soc. Hort Sci. 17:128-133.
Jones, H.A. 1923. Pollination and self-fertility in the onion. Proc. Amer. Soc. Hort. Sci. 20:191197.

Jones, H.A. 1927. Pollination and life history studies of lettuce (Lactuca sativa L.). Hilgardia 2:425-479.

Jones, H.A. 1927. The influence of storage temperature on seed production in the Ebenezer onion. Proc. Amer. Soc. Hort. Sci. 24:61-63.

Jones, H.A. 1929. Spacing, time-of-planting and size-of-seedling studies with the California Early Red onion. Proc. Amer. Soc. Hort. Sci. 26:114118 .

Jones, H.A. 1932. Spacing studies with male and female asparagus plants. Die Gartenbauwissenschaft. 6.

Jones, H.A. 1932. Vegetable breeding at the University of California-Presidential address. Proc. Amer. Soc. Hort. Sci. 29:572-581.

Jones, H.A. 1937. Onion improvement. Breeding Vegetable Crops. USDA Yrbk Sep. 1581:233250.

Jones, H.A. 1944. An autobiography. Herbertia 11:35-36.

Jones, H.A., S.F. Bailey, and S.L. Emsweller. 1934. Thrips resistance in the onion. Hilgardia 8:215-232.

Jones, H.A. and V.R. Boswell. 1922. Time of flower primordia formation in the onion (Allium cepa L.). Proc. Amer. Soc. Hort. Sci. 19:144147.
Jones, H.A. and A.E. Clarke. 1943. Inheritance of male sterility in the onion and the production of hybrid seed. Proc. Amer. Soc. Hort. Sci. 43:189-194.

Jones, H.A. and S.L. Emsweller. 1933. Methods of breeding onions. Hilgardia 7:625-642.

Jones, H.A. and S.L. Emsweller. 1934. The use of flies as onion pollinators. Proc. Amer. Soc. Hort. Sci. 31:160-164.

Jones, H.A. and S.L. Emsweller. 1936. A malesterile onion. Proc. Amer. Soc. Hort. Sci. 34:582-585

Jones, H.A. and L.K. Mann. 1963. Onions and their allies. Interscience, New York.

Jones, H.A., D.M. McLean, and B.A. Perry. 1956 Breeding hybrid spinach resistant to mosaic and downy mildew. Proc. Amer. Soc. Hort. Sci. 68:304-308.

Jones, H.A. and B.A. Perry. 1956. Inheritance of resistance to pink root in the onion. J. Hered. 47:33-34.

Jones, H.A., D.R. Porter, and L.D. Leach. 1939. Breeding for resistance to onion downy mildew caused by Peronospora destructor. Hilgardia 12:531-550.

Jones, H.A. and W.W. Robbins. 1924. Growing and handling asparagus crowns. Calif. Agr. Ext. Sta. Bul. 381

Jones, H.A. and W.W. Robbins. 1926. Influence of cutting asparagus the first year after planting on production the following year. Proc. Amer. Soc. Hort. Sci. 23:23-28.

Jones, H.A. and W.W. Robbins. 1928. The asparagus industry in California. Calif. Agr. Expt. Sta. Bul. 446.

Jones, H.A. and J.T. Rosa. 1928. Truck crop plants. McGraw-Hill, New York.

Jones, H.A. and AA. Tavernetti. 1932. The headlettuce industry of California. Calif. Agr. Ext. Circ. 60

Jones, H.A., J.C. Walker, T.M. Little, and R.H Larsen. 1946. Relation of color inhibiting factor to smudge resistance in onions. J. Agr. Res. 72:259-264

Perry, B.A. and H.A. Jones. 1955. Performance of short-day, pink-root resistant varieties of onions in Southern Texas. Proc. Amer. Soc. Hort. Sci. 66:350-353.

Porter, D.R. and H.A. Jones. 1933. Resistance of some cultivated species of Allium to pink root (Phoma terrestris). Phytopathology 23:290-298.

Robbins, W.W. and H.A. Jones. 1925. Secondary sex characters in Asparagus officinalis L. Hilgardia 1:183-202.

Robbins, W.W. and H.A. Jones. 1926. Sex as a factor in growing asparagus. Proc. Amer. Soc. Hort. Sci. 23:19-23.

Walker, J.C., H.A. Jones, and A.E. Clarke. 1944. Smut resistance in an Allium species hybrid. J. Agr. Res. 69:1-8.

Walker, J.C., H.A. Jones, and A.E. Clarke. 1944 Onion set production.U.S. Dept. Agr. Farmer's Bul. 1955.

Whitaker, T.W. 1983. Dedication: Henry A. Jones (1889-1981) plant breeder extraordinaire. Plant Breeding Rev. 1:1-10. 